University of Nebraska - Lincoln

DigitalCommons@University of Nebraska - Lincoln

U.S. Environmental Protection Agency Papers

U.S. Environmental Protection Agency

2005

\title{
Regional scale evidence for improvements in surface water chemistry 1990-2001
}

\author{
B. L. Skjelkvåle \\ Norwegian Institute for Water Research, P.O. Box 173, Kjelsa ${ }^{\circ}$, N-0411 Oslo, Norway \\ J. L. Stoddard \\ U.S. Environmental Protection Agency, 200 SW 35th Street, Corvallis, OR 97333, USA \\ D. S. Jeffries \\ Environment Canada, National Water Research Institute, Burlington, Ont., Canada \\ K. Tørseth \\ Norwegian Institute for Air Research, Kjeller, Norway \\ T. Høgåsen \\ Norwegian Institute for Water Research, P.O. Box 173, Kjelsa ${ }^{\circ}$, N-0411 Oslo, Norway \\ See next page for additional authors
}

Follow this and additional works at: https://digitalcommons.unl.edu/usepapapers

Part of the Civil and Environmental Engineering Commons

Skjelkvåle, B. L.; Stoddard, J. L.; Jeffries, D. S.; Tørseth, K.; Høgåsen, T.; Bowman, J.; Mannio, J.; Monteith, D.T.; Mosello, R.; Rogora, M.; Rzychon, D,; Vesely, J.; Wieting, J.; Wilander, A.; and Worsztynowicz, A., "Regional scale evidence for improvements in surface water chemistry 1990-2001" (2005). U.S. Environmental Protection Agency Papers. 24.

https://digitalcommons.unl.edu/usepapapers/24

This Article is brought to you for free and open access by the U.S. Environmental Protection Agency at DigitalCommons@University of Nebraska - Lincoln. It has been accepted for inclusion in U.S. Environmental Protection Agency Papers by an authorized administrator of DigitalCommons@University of Nebraska - Lincoln. 


\section{Authors}

B. L. Skjelkvåle; J. L. Stoddard; D. S. Jeffries; K. Tørseth; T. Høgåsen; J. Bowman; J. Mannio; D.T. Monteith; R. Mosello; M. Rogora; D, Rzychon; J. Vesely; J. Wieting; A. Wilander; and A. Worsztynowicz 


\title{
Regional scale evidence for improvements in surface water chemistry 1990-2001
}

\author{
B.L. Skjelkvåle, ${ }^{a}$, J.L. Stoddard ${ }^{b}$, D.S. Jeffries ${ }^{c}, K^{\prime}$. Tørseth ${ }^{d}$, T. Høgåsen ${ }^{a}$, \\ J. Bowman ${ }^{\mathrm{e}}$, J. Mannio ${ }^{\mathrm{f}}$, D.T. Monteith ${ }^{\mathrm{g}}$, R. Mosello ${ }^{\mathrm{h}}$, M. Rogora ${ }^{\mathrm{h}}$,

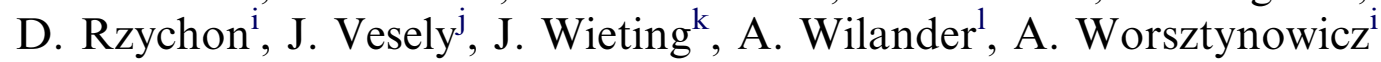 \\ ${ }^{a}$ Norwegian Institute for Water Research, P.O. Box 173, Kjelsås, N-0411 Oslo, Norway \\ ${ }^{\mathrm{b}}$ U.S. Environmental Protection Agency, $200 \mathrm{SW}$ 35th Street, Corvallis, OR 97333, USA \\ ${ }^{\mathrm{c}}$ Environment Canada, National Water Research Institute, Burlington, Ont., Canada \\ ${ }^{\mathrm{d}}$ Norwegian Institute for Air Research, Kjeller, Norway \\ ${ }^{\mathrm{e}}$ Environmental Protection Agency, Dublin, Ireland \\ ${ }^{\mathrm{f}}$ Finnish Environment Institute, Helsinki, Finland \\ ${ }^{\mathrm{g}}$ Environmental Change Research Centre, London, UK \\ ${ }^{\mathrm{h}}$ CNR Institute of Ecosystem Study, Verbania Pallanza, Italy \\ ${ }^{\mathrm{i}}$ Institute for Ecology of Industrial Areas, Katowice, Poland \\ ${ }^{\mathrm{j}}$ Czech Geological Survey, Prague, Czech Republic \\ ${ }^{\mathrm{k}}$ Umweltbundesamt, Berlin, Germany \\ ${ }^{1}$ Swedish University of Agricultural Sciences, Uppsala, Sweden
}

Received 31 October 2004; accepted 17 December 2004

Data demonstrates a continued regional-scale chemical response of acid sensitive lakes and streams to emissions controls programs which is conducive to biological recovery.

\begin{abstract}
The main aim of the international UNECE monitoring program ICP Waters under the Convention of Long-range Transboundary Air Pollution (CLRTAP) is to assess, on a regional basis, the degree and geographical extent of the impact of atmospheric pollution, in particular acidification, on surface waters. Regional trends are calculated for 12 geographical regions in Europe and North America, comprising 189 surface waters sites. From 1990-2001 sulphate concentrations decreased in all but one of the investigated regions. Nitrate increased in only one region, and decreased in three North American regions. Improvements in alkalinity and $\mathrm{pH}$ are widely observed. Results from the ICP Waters programme clearly show widespread improvement in surface water acid-base chemistry, in response to emissions controls programs and decreasing acidic deposition. Limited site-specific biological data suggest that continued improvement in the chemical status of acid-sensitive lakes and streams will lead to biological recovery in the future.
\end{abstract}

(C) 2005 Published by Elsevier Ltd.

Keywords: Acidification; Deposition; Trends; ICP waters; Sulphate; Nitrate; Alkalinity; Dissolved organic carbon

\footnotetext{
* Corresponding author.

E-mail address: brit.skjelkvaale@niva.no (B.L. Skjelkvåle).
}

\section{Introduction}

Surface water acidification has been recognized as a major environmental problem in many parts of Europe and North America for several decades, resulting in the 
creation of emissions control programs at both national and international levels. These programs have produced widespread decreases in acidic deposition, and the expectation that surface waters in affected regions should be experiencing recovery from acidification. In this paper we examine data from the international UNECE monitoring program ICP Waters (International Cooperative Programme on Assessment and Monitoring of Rivers and Lakes) under the Convention of Longrange Transboundary Air Pollution (UNECE, 1999; Bull et al., 2001) to determine whether such widespread recovery can be detected, and to put the more detailed results presented in this special issue for the UK Acid Waters Monitoring Network (AWMN) into a larger context. The ICP Waters network described in this paper covers most of the acid-sensitive terrain of the Northern Hemisphere, where emissions controls to control acidification have been focused. It is probably worth noting, however, that it does not cover areas (notably Asia) where acidic deposition is on the rise, and is of growing concern (Streets et al., 2001).

Our focus is primarily on trends in the chemistry of acid-sensitive surface waters. When these trends are shown to be moving in the correct direction (e.g., decreases in sulphate, $\mathrm{SO}_{4}^{2-}$, or increases in $\mathrm{pH}$ ), they indicate improvement in the acid-base chemistry of lakes and streams. It is important to note that these improvements or recovery process do not necessarily equate to recovery, for at least two important reasons:

1. Lakes and streams will have "recovered" only when their chemistry has returned to its pre-acidified status, such as pre-industrial levels of $\mathrm{SO}_{4}^{2-}$ or alkalinity, or to some status that no longer poses a risk to biotic integrity; trends indicate only that surface waters are moving toward this recovered status, not that they have reached it;

2. While the ultimate goal of emissions control programs is biological recovery, e.g., the return of sensitive species that have been eliminated and biological functioning that has been impaired during the course of acidification; chemical recovery is necessary before biological recovery can occur. Chemical data are more widely available and indicate weather the necessary chemical conditions to facilitate biological recovery is present or will be achieved.

3. This regional trend assessment is based on the premise that a consistent pattern of improvement (decreasing $\mathrm{SO}_{4}^{2-}$ and increasing $\mathrm{pH}$ and alkalinity) across a large number of sites represents the strongest evidence that emissions control programs are having their intended effect. For this reason, we aggregate data from numerous ICP Waters sites into regions, and conduct the trend tests on the region as a whole for all data collected in the time period
1990-2001. This period is one in which all of the regions covered by the ICP monitoring sites have experienced substantial reductions in sulphur (S) deposition (Barret et al., 2000; Stoddard et al., 2003; see also Davies et al., this issue), and this can be expected to be reflected in trends in surface water $\mathrm{SO}_{4}^{2-}$ concentrations and acidity ( $\mathrm{pH}$ and alkalinity).

Our analysis of response to changing deposition focuses on the key variables that play major roles in surface water acidification and recovery:

1. $\mathrm{SO}_{4}^{2-}$ and $\mathrm{NO}_{3}^{-}$, the acid anions of acidic deposition. Trends in the concentrations of these anions reflect recent trends in deposition (especially $\mathrm{SO}_{4}^{2-}$ ) and in ecosystem response to long-term deposition (most notably $\mathrm{NO}_{3}^{-}$and desorbed $\mathrm{SO}_{4}^{2-}$ ).

2. Base cations - as represented by $\Sigma\left(\mathrm{Ca}^{2+}+\mathrm{Mg}^{2+}\right)$ are mobilized by weathering reactions and cation exchange. Base cations will respond indirectly to decreases in $\mathrm{SO}_{4}^{2-}$ and $\mathrm{NO}_{3}^{-}$because reduced input of acids will theoretically lead to reduction of neutralizing processes in the soil, such as weathering and ion-exchange, and thereby reduced release of base cations to soil- and runoff water.

3. Acidity, including $\mathrm{pH}$, measured (Gran) alkalinity and calculated ANC, which reflects the outcome of interactions between changing concentrations of acid anions and base cations.

4. Concentrations of Dissolved Organic Carbon (DOC) or alternatively Total Organic Carbon (TOC), as a surrogate for organic acidity. Organic acids are common natural sources of acidity in surface waters.

The ICP Waters network consists of acid-sensitive lakes and streams in 23 countries of Europe and North America. Sites in the ICP Waters database exhibit a wide range of sampling frequencies, completeness of chemistry, and length of record. Although monitoring at some sites extends further back than 1988, when sampling on the AWMN was initiated, the ICP Waters Network only reached its current size in the early 1990s. As the focus for the remainder of this special issue is the 1988-2003 period in the UK it is therefore not possible to make precise temporal comparisons between the two datasets. In order to make a meaningful comparison of trends among these sites, we imposed a minimum set of requirements (e.g., for sampling frequency, completeness of major ion chemistry, etc.) for inclusion of data, which are described in detail in Skjelkvåle et al. (2003b). A total of 189 sites had sufficient data to be included in our analyses. Details of the ICP Waters program, data quality control, and the collection and measurement of the variables listed above, can be found in numerous ICP Waters reports 
(International Cooperative Programme on Assessment and Monitoring of Acidification of Rivers and Lakes, 1995; Skjelkvåle et al., 2003b). Both $\mathrm{SO}_{4}^{2-}$ and base cation concentrations were sea-salt corrected prior to analysis, and the analyses of $\mathrm{pH}$ were made on values transformed to $\mathrm{H}^{+}$concentrations.

\section{Statistical methods}

Numerous statistical techniques are available to analyse trends in time series such as those presented here. In the two previous ICP Waters reports we have used the Seasonal Kendall test (SKT) (Hirsch and Slack, 1984; Hirsch et al., 1982). This method deals well with censored data, and with data collected at irregular intervals with marked seasonality (Loftis and Taylor, 1989). The SKT, however, is designed to estimate the statistical significance of trends, and does not include a direct estimate of the magnitude of the trends. The regional analyses we present in this report depend on the ability to calculate a robust estimator of slope for each site. Rather than utilizing a Theil or Sen estimator of slope, as is often done with the SKT, we have chosen to employ simple linear regression (SLR) to calculate a robust slope for trends at each monitoring site.

While the significance of individual tests conducted with SLR are questionable (due to lack of normality in the monitoring data, and the use of multiple comparisons when combining results from many sites in a region), we can use the estimated SLR slopes to indicate the range of behaviours (i.e., rates and directions of change) observed in each region. For any given variable in any given region, the collection of slopes represents a distribution whose central tendency is characterized by the median value (slope) for the region. We test for the significance of trends in the region by calculating confidence limits about the median value in the slope distribution (Altman et al., 2000; SAS Institute Inc., 1988), and testing whether these confidence limits include zero. For a distribution in which all of the slopes are negative, for example, the median value would be significantly less than zero, indicating a significant regional downward trend.

\section{Regional trend results}

Regional trends were calculated for 12 regions (6 in Europe and 6 in North America), comprising 189 ICP Waters sites (73 in Europe and 116 in North America); both regions and the locations of individual sites are illustrated in Fig. 1. The sites are grouped into geographic regions based on similar acid-sensitivity (e.g., similar geology, soil characteristics) and rates of deposition. In some cases, in order to reach sufficient sample sizes (i.e., number of sites), we have grouped sites into regions that are more heterogeneous than would be ideal. For example, the "Upper Midwest" region of the U.S. and Canada includes sites in central Ontario (the Turkey Lakes area), western Ontario (Experimental Lakes Area), northern Michigan and northern Wisconsin. While there are certainly many similarities in the geology of these areas, they comprise a very large geographic area with different climate and rate of change of atmospheric deposition. The list of regions on which we report is therefore based on both scientific and pragmatic decisions resulting from availability of data. The UK/Ireland group consists of six lakes from the AWMN and three from the Republic of Ireland.

Results of trend analyses in each region are shown in Table 1.

\subsection{Sulphate}

The most significant finding in this regional trend analysis, as in others conducted on earlier data (Skjelkvåle et al., 2001b; Stoddard et al., 1999), is the almost universal decrease in $\mathrm{SO}_{4}^{2-}$ concentrations in lakes and streams throughout Europe and North America (Table 1, Fig. 2). Only one region in this analysis failed to show a significant $\mathrm{SO}_{4}^{2-}$ decrease, and this is a region (the Virginia Blue Ridge) where strongly sulphur-adsorbing soils make a $\mathrm{SO}_{4}^{2-}$ decrease unlikely (Church et al., 1990; Cosby et al., 1986). Many decades of accumulated, atmospherically-deposited $\mathrm{SO}_{4}^{2-}$ is now slowly leaking out under reduced rates of $\mathrm{SO}_{4}^{2-}$ deposition. A small but significant increase in surface water $\mathrm{SO}_{4}^{2-}$ is most probably due to output of "old" stored $\mathrm{SO}_{4}^{2-}$ in the soils.

In Europe, regional rates of $\mathrm{SO}_{4}^{2-}$ decline ranged from ca. $-1 \mu$ eq $1^{-1} \mathrm{yr}^{-1}$ in the U.K. and Ireland and the Northern Nordic region, to more than $-6 \mu \mathrm{eq} 1^{-1} \mathrm{yr}^{-1}$ in the Southern Nordic region. Rates in central Europe were intermediate, with both East- and West-Central Europe exhibiting regional $\mathrm{SO}_{4}^{2-}$ declines of ca. $-4 \mu \mathrm{eq}$ $1^{-1} \mathrm{yr}^{-1}$. All of these changes are consistent with declines in rates of $\mathrm{S}$ deposition in Europe (see below).

Previous regional trend analyses of ICP data did not find decreases in $\mathrm{SO}_{4}^{2-}$ in the UK and Ireland, but the addition of data from the late 1990s and early 2000s leads to a highly significant rates of $\mathrm{SO}_{4}^{2-}$ decline (Table 1). This is consistent with the trends reported for the larger AWMN dataset over 1988-2003 (Davies et al., this issue).

In North America, rates of $\mathrm{SO}_{4}^{2-}$ decline ranged from ca. $-1 \mu \mathrm{eq} 1^{-1} \mathrm{yr}^{-1}$ in the region with the lowest rates of $\mathrm{S}$ deposition (Maine and Atlantic Canada), to more than $-2 \mu \mathrm{eq} 1^{-1} \mathrm{yr}^{-1}$ in the Adirondack Mountains, Appalachian Mountains, and the Upper Midwest (U.S. and Canada). In an analysis of recent trends in both surface waters and deposition, Stoddard et al. (2003) 


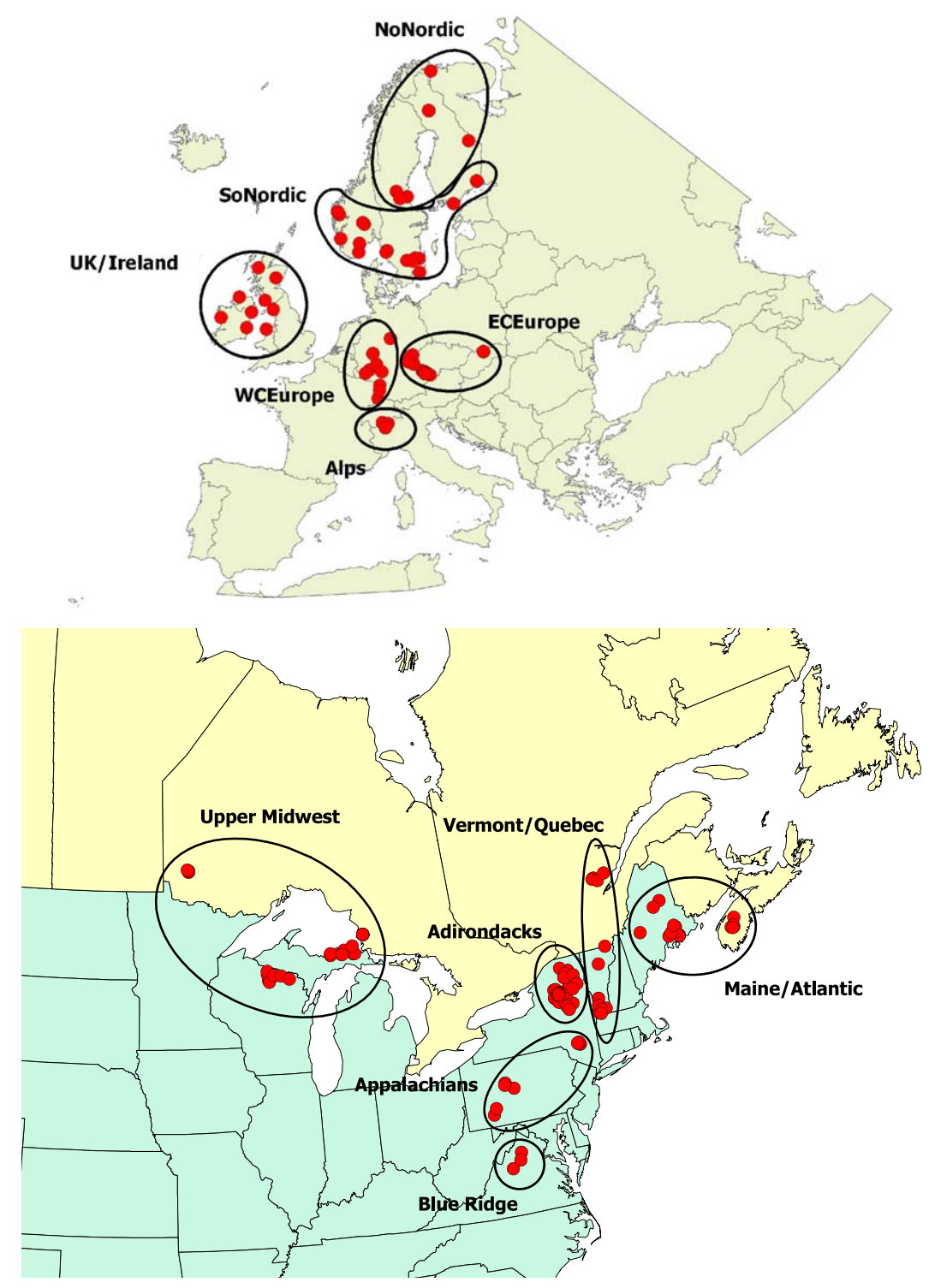

Fig. 1. Map showing location of ICP Waters sites used for trend analysis in this report and outline of geographical regions.

conclude that rates of $\mathrm{SO}_{4}^{2-}$ decline in surface waters follow the same geographic pattern, but are lower than, trends in regional $\mathrm{SO}_{4}^{2-}$ deposition.

\subsection{Nitrate}

Fewer than half of the ICP regions exhibited significant regional trends in $\mathrm{NO}_{3}^{-}$(Table 1), and only the Alps region showed a significant increase. Regional declines in $\mathrm{NO}_{3}^{-}$since ca. 1990 have been noted elsewhere (Skjelkvåle et al., 2001b; Stoddard et al., 1999), and need to be interpreted cautiously. The time period of data analysed in this analysis, and in previous reports, is on the order of a decade. While decadal trends in ions undergoing incremental and consistent changes (i.e., $\mathrm{SO}_{4}^{2-}$ ) can be interpreted as an improvement in acid-base chemistry, they may not represent true long-term changes for ions actively affected by biotic processes and thus as temporally variable as $\mathrm{NO}_{3}^{-}$. Both mathematical (Aber et al., 1997) and conceptual (Stoddard, 1994; Wright et al., 2001) models of nitrogen suggest that long-term catchment responses to $\mathrm{N}$ deposition may occur on the time scale of centuries, rather than decades. Several large scale analyses of $\mathrm{NO}_{3}^{-}$ data suggest the strong spatial patterns observed, with the highest $\mathrm{NO}_{3}^{-}$concentrations occurring in regions of highest $\mathrm{N}$ deposition, can only be explained by longterm accumulation and eventual leakage of atmospherically-deposited $\mathrm{NO}_{3}^{-}$from catchment soils and vegetation (Dise and Wright, 1995; Stoddard et al., 2001). A recent comprehensive assessment of North American data has shown that these spatial patterns are evident in forest foliage, soils and surface waters (Aber et al., 2003), and concludes that many of the trends 
Table 1

Regional trend results for ICP Waters sites for the period 1990-2001

\begin{tabular}{|c|c|c|c|c|c|c|c|c|c|}
\hline \multirow[t]{2}{*}{ Region } & \multirow[t]{2}{*}{ Continent } & \multirow[t]{2}{*}{ \# sites } & \multicolumn{7}{|c|}{ Slope of regional trend in: } \\
\hline & & & $\mathrm{SO}_{4}^{2-}$ & $\mathrm{NO}_{3}^{-}$ & Gran Alkalinity & $\mathrm{ANC}$ & $\mathrm{H}^{+}$ & $\mathrm{Ca}+\mathrm{Mg}$ & DOC \\
\hline Alps & Europe & 6 & -1.80 & +0.52 & +1.05 & -0.02 & +0.00 & -1.35 & $*$ \\
\hline East Central Europe & Europe & 20 & -3.91 & -0.87 & +0.41 & +2.55 & -0.13 & -2.26 & +0.06 \\
\hline Northern Nordic & Europe & 7 & -1.68 & +0.00 & +0.72 & +0.26 & -0.07 & -1.23 & +0.05 \\
\hline Southern Nordic & Europe & 19 & -6.75 & -0.05 & +1.73 & +3.30 & -0.16 & -2.58 & +0.08 \\
\hline UK/Ireland & Europe & 9 & -1.45 & +0.02 & +1.37 & +0.33 & -0.29 & -1.46 & +0.13 \\
\hline West Central Europe & Europe & 12 & -3.95 & -1.00 & $*$ & +6.02 & +0.02 & -5.42 & +0.03 \\
\hline Maine/Atlantic Canada & N. America & 18 & -1.02 & +0.00 & -0.59 & -0.32 & +0.00 & -1.39 & +0.04 \\
\hline Vermont/Quebec & N. America & 15 & -2.20 & -0.20 & +0.26 & +0.94 & -0.05 & -1.40 & +0.06 \\
\hline Adirondacks & N. America & 48 & -2.26 & -0.47 & +1.03 & +1.19 & -0.19 & -2.29 & +0.06 \\
\hline Appalachian Plateau & N. America & 9 & -2.27 & -1.37 & +0.79 & +1.92 & -0.08 & -2.97 & +0.03 \\
\hline Upper Midwest & N. America & 23 & -2.47 & +0.02 & +0.32 & +0.90 & -0.01 & -1.80 & +0.06 \\
\hline Virginia Blue Ridge & N. America & 3 & +0.35 & -1.36 & +0.06 & $*$ & -0.00 & -0.58 & -0.04 \\
\hline
\end{tabular}

Values are median slope for the region, with significant results $(P<0.05)$ shown in bold and italics. Units for sulphate, nitrate, base cations $\left[\mathrm{Ca}^{2+}+\mathrm{Mg}^{2+}\right]$, Gran alkalinity, ANC and hydrogen are $\mu$ eq $\mathrm{l}^{-1}$ year ${ }^{-1}$. Units for DOC are $\mathrm{mg}^{-1}$ year $^{-1} . *$ insufficient data.

reported for lake and stream $\mathrm{NO}_{3}^{-}$may represent only the short-term variation in a large-scale and long-term increase in $\mathrm{NO}_{3}^{-}$due to $\mathrm{N}$ saturation (see also Curtis et al., 2005, in this issue).

Over the 12-year period 1990-2001, ICP sites show decreasing $\mathrm{NO}_{3}^{-}$concentrations in the Adirondack Mountains, Appalachian Mountains and the Virginia Blue Ridge (all in North America), and increasing concentrations in the Alps (Fig. 3). The area in northwestern Italy where the ICP Waters sites are located is subject to a high atmospheric input of $\mathrm{N}$

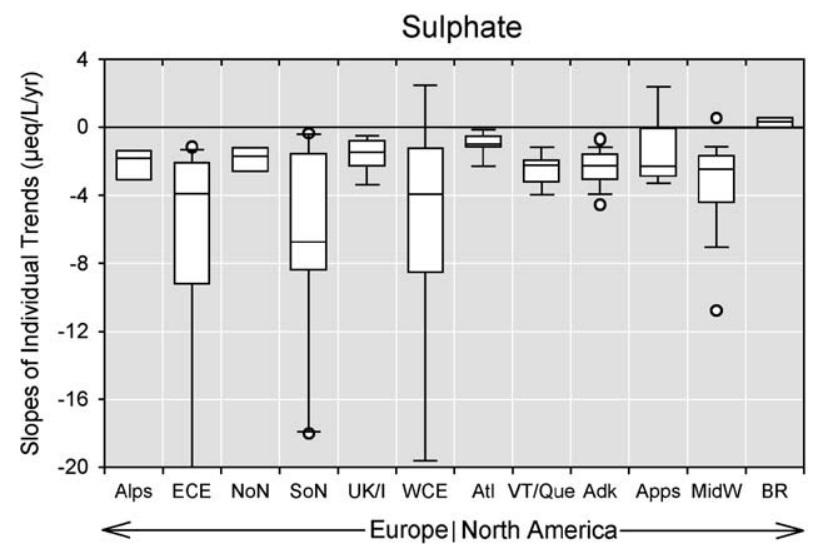

Fig. 2. Distributions of slopes for $\mathrm{SO}_{4}^{2-}$ trends in ICP regions in Europe and North America. Each box shows the range (25th to 75th percentiles, with line at median) of slopes; confidence intervals indicate 10th and 90th percentiles; dots indicate 5th and 95th percentiles. Significance of regional trend is indicated by preponderance of slope values (e.g., 95\%) either above or below zero. Abbreviated region names are: $\mathrm{ECE}=$ East-Central Europe; $\mathrm{NoN}=$ Northern Nordic; SoN $=$ Southern Nordic; UK $/ \mathrm{I}=$ United Kingdom and Republic of Ireland; WCE $=$ West-Central Europe; Atl=Maine and Atlantic Canada; VT $/$ Que $=$ Vermont and Quebec; Adk=Adirondack Mountains; Apps = Appalachian Plateau; MidW=Upper Midwestern U.S. and Canada; $\mathrm{BR}=$ Virginia Blue Ridge. compounds $\left(25-30 \mathrm{~kg} \mathrm{ha}^{-1} \mathrm{yr}^{-1}\right.$ as the sum of ammonium and $\mathrm{NO}_{3}^{-}$) which has remained fairly constant in the last two decades causing increasing $\mathrm{N}$ saturation in forest ecosystems and increasing $\mathrm{NO}_{3}^{-}$ levels in rivers and lakes (Rogora et al., 2001). No other regions exhibit clear patterns (Fig. 3) and once more, the absence of trend in the UK/Ireland group is consistent with the observations of Davies et al. (this issue) for the wider UK.

Some sites in Central Europe show increasing trends due to forest disturbance (harvesting or insects), while other sites in sensitive areas show decreasing trends. Vesely et al. (2002) have shown that $\mathrm{NO}_{3}^{-}$in stream waters with $\mathrm{pH}$ less than or equal to 6 has decreased up to $60 \%$ between $1984-1986$ and $1996-2000$ in the Czech Republic. This rate of decline is greater than the $35 \%$ decrease of $\mathrm{N}$ emission observed in central Europe in the same period.

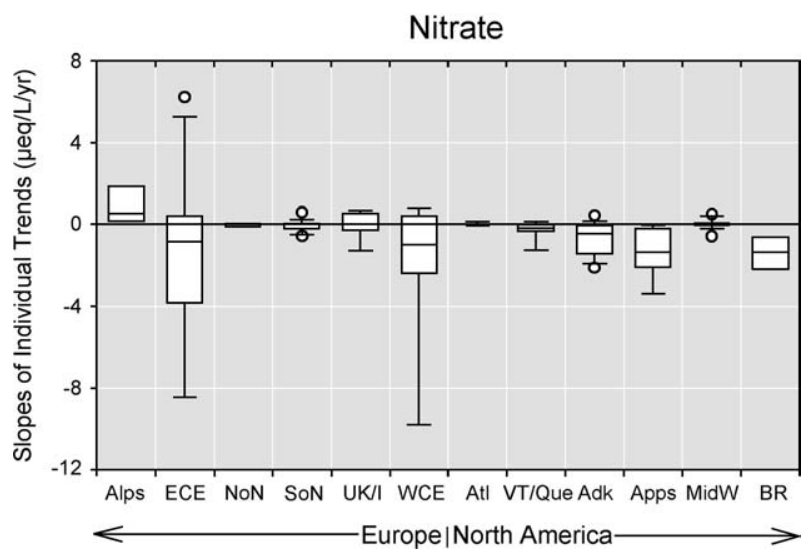

Fig. 3. Distributions of slopes for $\mathrm{NO}_{3}^{-}$trends in ICP regions in Europe and North America. Interpretation of box and whiskers, as well as regional abbreviations, are as in Fig. 2. 


\subsection{Base cations}

One of the expected responses of catchments to decreasing $\mathrm{SO}_{4}^{2-}$ is a decrease in base cation concentrations (Galloway et al., 1983). In this report, we use the sum of calcium and magnesium $(\mathrm{Ca}+\mathrm{Mg})$ as a surrogate for total base cations, because these cations are the most quantitatively important at the majority of acid sensitive monitoring sites, and because they exert the most control over alkalinity (Stoddard et al., 2003). As expected, all of the ICP regions show tendencies toward decreasing $\mathrm{Ca}+\mathrm{Mg}$ (Fig. 4). One of the key findings of earlier regional assessments (Skjelkvåle et al., 2001b; Stoddard et al., 1999) is the larger-than-expected decreases in $\mathrm{Ca}+\mathrm{Mg}$ in some regions, particularly in North America. When rates of $\mathrm{Ca}+\mathrm{Mg}$ decline are equal, or nearly equal, to rates of $\mathrm{SO}_{4}^{2-}$ and $\mathrm{NO}_{3}^{-}$ decline, then chemical improvement (increasing alkalinity and $\mathrm{pH}$ ) is negligible.

In the European regions, rates of $\mathrm{Ca}+\mathrm{Mg}$ decrease are mostly smaller than those for $\mathrm{SO}_{4}^{2-}$ (Table 1, Fig. 4). One important exception is the U.K. and Ireland, where rates of rates of $\mathrm{SO}_{4}^{2-}$ and $\mathrm{Ca}+\mathrm{Mg}$ decline were nearly equal for the time period 1990-2001-this has important implications for improvements in acidity in this region (see discussion below). One North America region (Maine and Atlantic Canada) exhibited stronger decreasing trends in $\mathrm{Ca}+\mathrm{Mg}$ than in $\mathrm{SO}_{4}^{2-}$.

\subsection{Gran alkalinity and $A N C$}

Because $\mathrm{SO}_{4}^{2-}$ is declining regionally in almost all ICP regions, and $\mathrm{NO}_{3}^{-}$is either declining or unchanged in all but one region, we expect to see increases in the key indicators of recovery from acidification: Gran alkalinity, charge-balance ANC (acid neutralizing capacity) and $\mathrm{pH}$ (decline in $\mathrm{H}^{+}$). Gran alkalinity is a measured variable that indicates the water's ability to buffer acidic

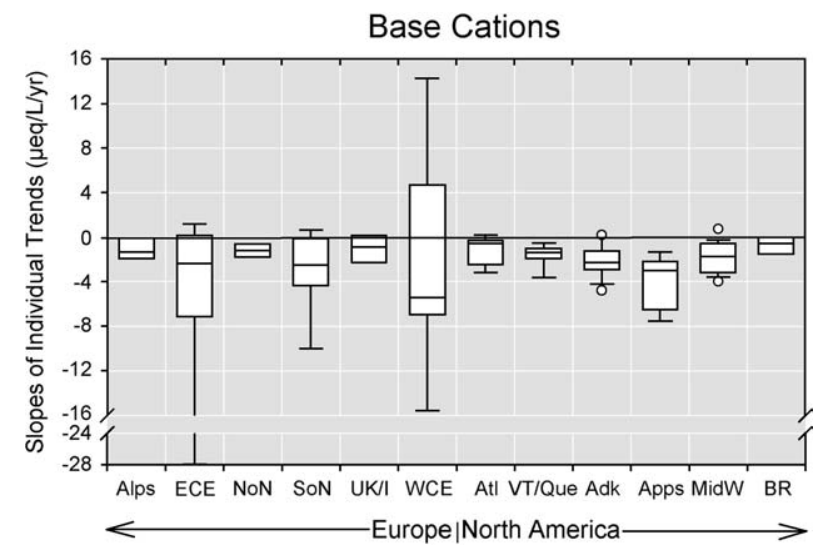

Fig. 4. Distributions of slopes for base cation $(\mathrm{Ca}+\mathrm{Mg})$ trends in ICP regions in Europe and North America. Interpretation of boxes and whiskers, as well as region abbreviations are as in Fig. 2. inputs. ANC is calculated as an approximation for alkalinity. Charge-balance ANC is defined as the equivalent sum of base cations minus the equivalent sum of strong acid anions, and is particularly useful for regions where Gran alkalinity is not measured, and to compare to model outputs which are often made in terms of ANC rather than alkalinity. Most critical loads estimates depend on charge-balance ANC.

In the Alps, $\mathrm{SO}_{4}^{2-}$ is declining at a median rate of $-1.8 \mu \mathrm{eq} 1^{-1} \mathrm{yr}^{-1}$. Combined with a median increase in $\mathrm{NO}_{3}^{-}$of $+0.5 \mu \mathrm{eq} \mathrm{I}^{-1} \mathrm{yr}^{-1}$, the Alps exhibit an overall change in acid anion concentrations of $-1.3 \mu \mathrm{eq} 1^{-1}$ $\mathrm{yr}^{-1}$, and a significant increase in Gran alkalinity of ca. $+1 \mu$ eq $1^{-1} \mathrm{yr}^{-1}$ (Table 1, Fig. 5).

In East-Central Europe, the decline in $\mathrm{SO}_{4}^{2-}$ is -3.9 $\mu$ eq $1^{-1} \mathrm{yr}^{-1}$, considerably larger than the decline in base cations for this region $\left(-2.3 \mu \mathrm{eq} \mathrm{l}^{-1} \mathrm{yr}^{-1}\right) ; \mathrm{NO}_{3}^{-}$did not change significantly. While no significant increase in Gran alkalinity was observed for this region, calculated ANC increased strongly $\left(+2.6 \mu \mathrm{eq} 1^{-1} \mathrm{yr}^{-1}\right)$, consistent with the changes in $\mathrm{SO}_{4}^{2-}$ and $\mathrm{Ca}+\mathrm{Mg}$ (Table 1)-more than $75 \%$ of the ICP sites in East-Central Europe showed increases in ANC for the period 1990-2001. This represents significant improvement in acid-base status for sites in Poland, the Czech Republic, and eastern parts of Germany. A handful of sites in this region do not report Gran alkalinity values, which may explain the lack of significant results for alkalinity.

In the more remote Northern Nordic areas, rates of deposition have historically been lower than in the rest of Europe; as a result, acidification is much less severe, and rates of chemical improvement are not expected to be large. Nonetheless, this region exhibited significant declines in $\mathrm{SO}_{4}^{2-}\left(-1.7 \mu\right.$ eq $\left.1^{-1} \mathrm{yr}^{-1}\right)$, smaller declines in $\mathrm{Ca}+\mathrm{Mg}\left(-1.2 \mu \mathrm{eq}^{-1} \mathrm{yr}^{-1}\right)$ and a significant, though

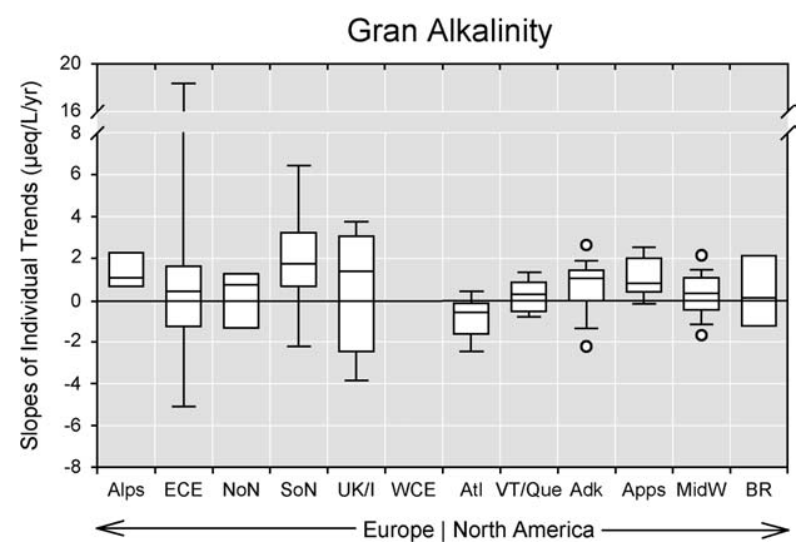

Fig. 5. Distributions of slopes for Gran alkalinity trends in ICP regions in Europe and North America. There were insufficient Gran alkalinity data available for West Central Europe to allow calculation of a regional trend. Interpretation of boxes and abbreviations as in Fig. 2. 
modest, increase in Gran alkalinity $\left(+0.7 \mu \mathrm{eq} 1^{-1} \mathrm{yr}^{-1}\right)$ (Table 1, Fig. 5).

By contrast, the Southern Nordic region has experienced high rates of acidic deposition, especially in past decades, and significant surface water acidification (e.g., Henriksen et al., 1998; Kamari et al., 1991; Skjelkvåle et al., 2001a). Improving acid-base status has been observed since ca. 1990 in the southern portions of Norway, Sweden and Finland (Skjelkvåle et al., 2001a; Stoddard et al., 1999), and continues into the 2000s (Table 1). During the period 1990-2001, this region experienced the largest observed decreases in surface water $\mathrm{SO}_{4}^{2-}$, no change in $\mathrm{NO}_{3}^{-}$, and strongly increasing Gran alkalinity $\left(+1.7 \mu \mathrm{eq} 1^{-1} \mathrm{yr}^{-1}\right.$; Table 1). More than $75 \%$ of ICP sites in the Southern Nordic region exhibited upward trends in Gran alkalinity, and all sites exhibited upward trends in ANC (Fig. 6).

The U.K./Ireland region experienced the most modest decreases in surface water $\mathrm{SO}_{4}^{2-}$ of any European ICP region, and they were very closely balanced stoichiometrically by decreasing $\mathrm{Ca}+\mathrm{Mg}$ (Table 1). As a result, we were unable to detect significant increases in either Gran alkalinity (Fig. 5) or calculated ANC (Fig. 6) in the UK and Ireland. These observations are largely in agreement with those of Davies et al. (this issue), although Davies et al. do demonstrate an apparent response to declining $\mathrm{SO}_{4}^{2-}$ when an alternative method of determining ANC is adopted based on DOC and labile Al. This latter method cannot be applied across the ICP dataset due to the absence of measured values of DOC and or labile Al data from some localities.

In West-Central Europe, we did not have sufficient Gran alkalinity data to perform reliable trend tests, and our conclusions regarding recovery are therefore based on calculated ANC (Table 1). This region exhibited substantial decreases in $\mathrm{SO}_{4}^{2-}\left(-4 \mu \mathrm{eq} 1^{-1} \mathrm{yr}^{-1}\right)$, but

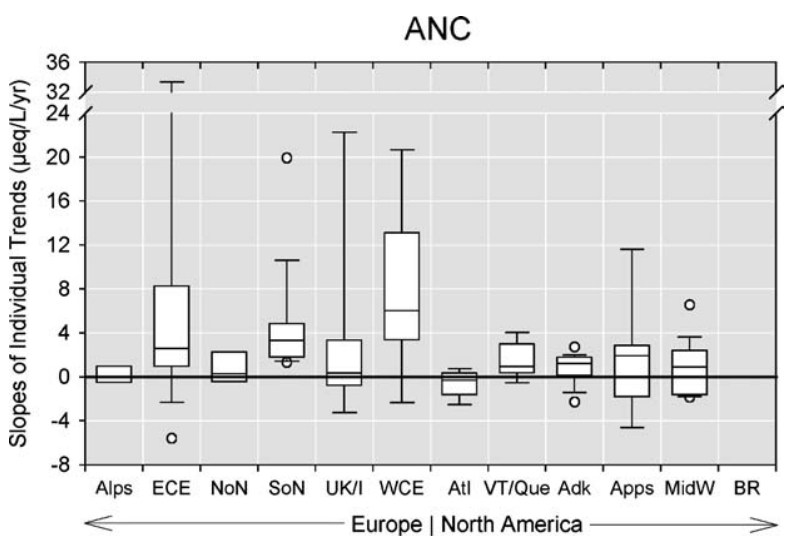

Fig. 6. Distributions of slopes for calculated ANC trends in ICP regions in Europe and North America. Interpretation of boxes and whiskers, as well as region names, are as in Fig. 2. (ANC values were not calculated for the Blue Ridge sites.) widely variable changes in $\mathrm{Ca}+\mathrm{Mg}$ (Fig. 4). Calculated ANC suggests a strong improvement in this region (+6 4 eq $1^{-1} \mathrm{yr}^{-1}$; Table 1, Fig. 6).

In North America three regions show significant improvement in either Gran alkalinity or ANC (Vermont/Quebec, Adirondacks and Appalachians), two exhibit no change (Upper Midwest and Virginia Blue Ridge), and one region is experiencing significant further acidification (Maine/Atlantic Canada). Movement toward recovery in the Adirondack and Appalachian mountains is an important finding, because neither of these regions showed significant improvement in previous regional analyses (e.g., Skjelkvåle et al., 2001b; Stoddard et al., 1999). All of these regions exhibit upward alkalinity trends that began in the early- to mid$1990 \mathrm{~s}$, and in all cases $75 \%$ or more of the individual sites have positive trend slopes (Fig. 5). In the Adirondacks, in particular, recent widespread improvement has received much attention, and includes increasing Gran alkalinity and $\mathrm{pH}$, as well as significant decreases in toxic aluminium (Driscoll et al., 2003; Stoddard et al., 2003). Evaluation of the changing pattern of chemical trends observed in Canadian lakes over the past ten years shows that there has been a gradual shift from "no response" to "recovery" although the degree of improvement is still clearly at a very early stage (Jeffries et al., 2003).

The Virginia Blue Ridge region is not experiencing, nor is it expected to experience, decreasing $\mathrm{SO}_{4}^{2-}$ concentrations. As a result, there is no expectation that Gran alkalinity will increase in the immediate future; the current analysis indicates there has been no significant change in alkalinity during 1990-2001 (Table 1).

The region of Maine and Atlantic Canada is the only ICP region where significant acidification has occurred during the 1990s and early 2000s. Gran alkalinity decreased at a rate of $-0.6 \mu$ eq $1^{-1} \mathrm{yr}^{-1}$ for the period 1990-2001 (Table 1, Fig. 5), and this acidification has occurred at the same time as significant (but small) decreases in surface water $\mathrm{SO}_{4}^{2-}$. Importantly, Maine/ Atlantic Canada is the only ICP region where $\mathrm{Ca}+\mathrm{Mg}$ declines $\left(-1.4 \mu \mathrm{eq} \mathrm{1}^{-1} \mathrm{yr}^{-1}\right)$ exceeded observed decreases in acid anions $\left(-1.0 \mu \mathrm{eq} 1^{-1} \mathrm{yr}^{-1}\right)$. This somewhat extreme base cation behaviour has been noted previously in other regions now undergoing significant improvement (e.g., Couture, 1995; Jeffries et al., 2002; Kirchner and Lydersen, 1995; Lawrence et al., 1999; Wilander and Lundin, 2000), and still has no accepted geochemical explanation. It appears currently to be limiting the rate of recovery in Maine and Atlantic Canada.

\section{5. $p H$}

Chemical improvement of surface water acid-base chemistry involves a combination of changes toward 
a historically more natural chemical composition. Included in these changes are decreases in $\mathrm{SO}_{4}^{2-}$ and potentially $\mathrm{NO}_{3}^{-}$(in regions where $\mathrm{NO}_{3}^{-}$has been a significant agent of acidification in the past), and increases in alkalinity and $\mathrm{pH}$. Of these changes, increases in $\mathrm{pH}$ are perhaps the most biologically relevant, due to the relation between low $\mathrm{pH}$ and high concentrations of toxic aluminium. In the current assessment we analyse trends in hydrogen ion (calculated from $\mathrm{pH}$ measurements). A decrease in hydrogen ion concentration implies an increase in $\mathrm{pH}$. Only two of the regions exhibit significant $\mathrm{H}^{+}$declines (the Southern Nordic and Adirondack regions; Table 1, Fig. 7). Both are among the regions showing the largest improvements in Gran alkalinity. $\mathrm{pH}$ is among the most difficult variables to measure well in the laboratory and variability in measurements makes it more difficult to detect trends. A longer data record might overcome inherent variability in the data, and lead to a conclusion of increasing $\mathrm{pH}$ in additional regions. The relatively large decrease in $\mathrm{H}^{+}$observed in UK/Ireland, for example, is not significant, possibly due to the small sample size used this analysis (see also Davies et al., this issue).

\subsection{Dissolved organic carbon}

Dissolved organic carbon (DOC) is of great interest in any analysis of surface water recovery, because it is an indicator of natural organic acidity (Driscoll et al., 1989). The previous ICP trends report (Skjelkvåle et al., 2001b) was one of the first to note the widespread increases in DOC now being observed throughout Europe and North America. All but one of the ICP regions included in this analysis exhibited positive slopes for DOC (Fig. 8), and six of these were considered

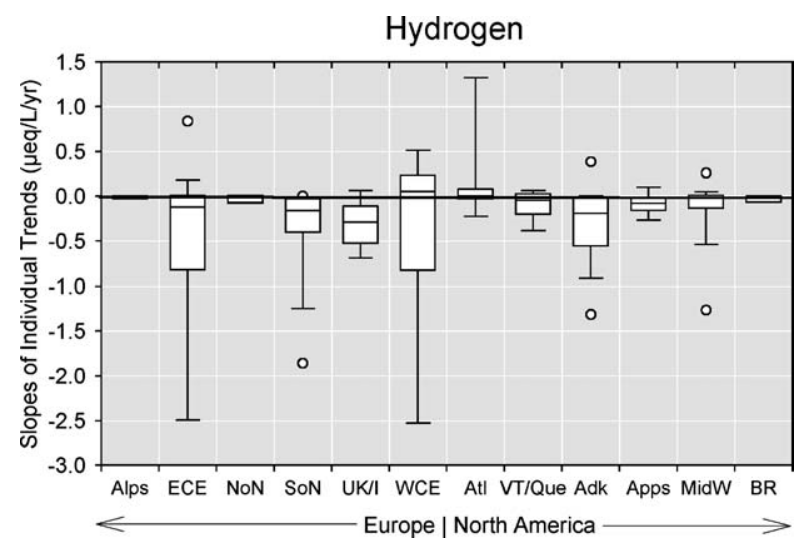

Fig. 7. Distributions of slopes for hydrogen ion trends in ICP regions in Europe and North America. Interpretation of boxes and whiskers, as well as region names, are as in Fig. 2. Increasing $\mathrm{pH}$ (an indicator of recovery) is the same as decreasing $\mathrm{H}^{+}$.

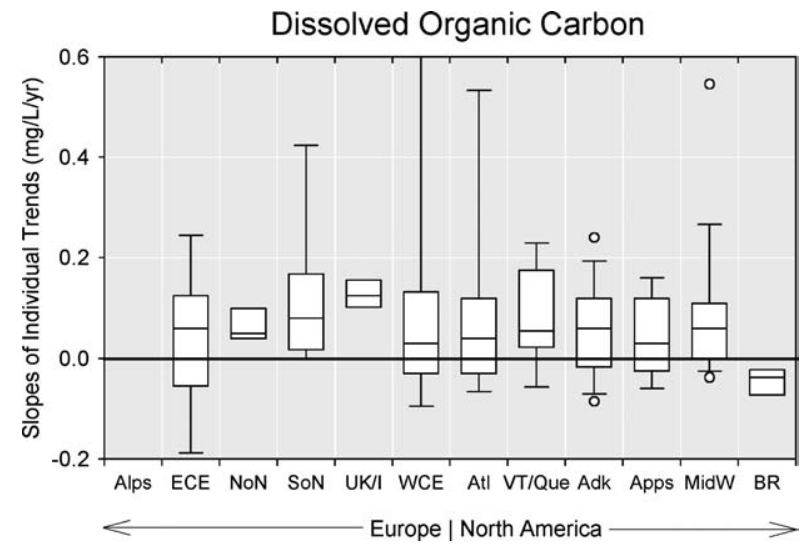

Fig. 8. Distributions of slopes for trends in dissolved organic carbon in ICP regions in Europe and North America. Interpretation of boxes and whiskers, as well as region names, are as in Fig. 2. Increasing DOC is an indicator of the increased importance of organic acids in the acid/ base chemistry of ICP sites.

significant. Overall, the results suggest an almost universal increase in the importance of organic acids.

Regional trends of increasing organic carbon through the 1990s have been documented from the UK (Freeman et al., 2001), the Nordic countries (Skjelkvåle et al., 2001a), elsewhere in Europe (Skjelkvåle et al., 2001b), and in the U.S. (Stoddard et al., 2003), while the picture is less straightforward in Canada (Jeffries et al., 2003). These increases may be coupled to warmer climate, particularly to elevated summer temperatures (Freeman et al., 2001), although the mechanism for observed changes is uncertain (e.g., Evans et al., 2002; Tranvik and Jansson, 2002) and may in part also be related to declining acid deposition (see Evans et al., this issue). If changes are temperature-driven, a warmer future climate may lead to further, and historically unprecedented, increases in DOC concentrations, with complex consequences for surface waters; these include increased organic acidity, increased buffering of changes in $\mathrm{pH}$, increased water coloration, and decreased visible light and UV-B penetration within the water column. Alternatively, if declining acid deposition is having a major influence, the rise in DOC concentration may be seen as part of the recovery process, with "weak" organic acidity increasingly replacing "strong" mineral acidity.

\subsection{Aluminium}

Our interest in chemical recovery from acidification generally stems not from a desire to measure chemical change, but to observe and predict the process of biological recovery. For this reason, many of the chemical variables we choose to analyse are selected because of their relevance to the biota. Of the variables discussed thus far, both Gran alkalinity and $\mathrm{pH}$ have 
important implications for biological recovery, both because of the direct toxic effects of elevated $\mathrm{H}^{+}$, and because of their controlling effects on toxic aluminium concentrations. Unfortunately, most participants in the ICP Waters program do not routinely measure labile or inorganic monomeric aluminium (the form most toxic to biota), and we cannot infer regional patterns in aluminium behaviour from the ICP data. We can, however, observe the patterns at individual sites; while they do not give us the confidence that regional declines in aluminium would give us, declining concentrations of labile aluminium at single sites do suggest that our expectations of improving aluminium concentrations, based on declining alkalinity and $\mathrm{H}^{+}$, are justified. An example of site-specific data for labile aluminium is shown in Fig. 9, for the Vikedal ICP site in western Norway. At Vikedal, pH began increasing ca. 1990, in

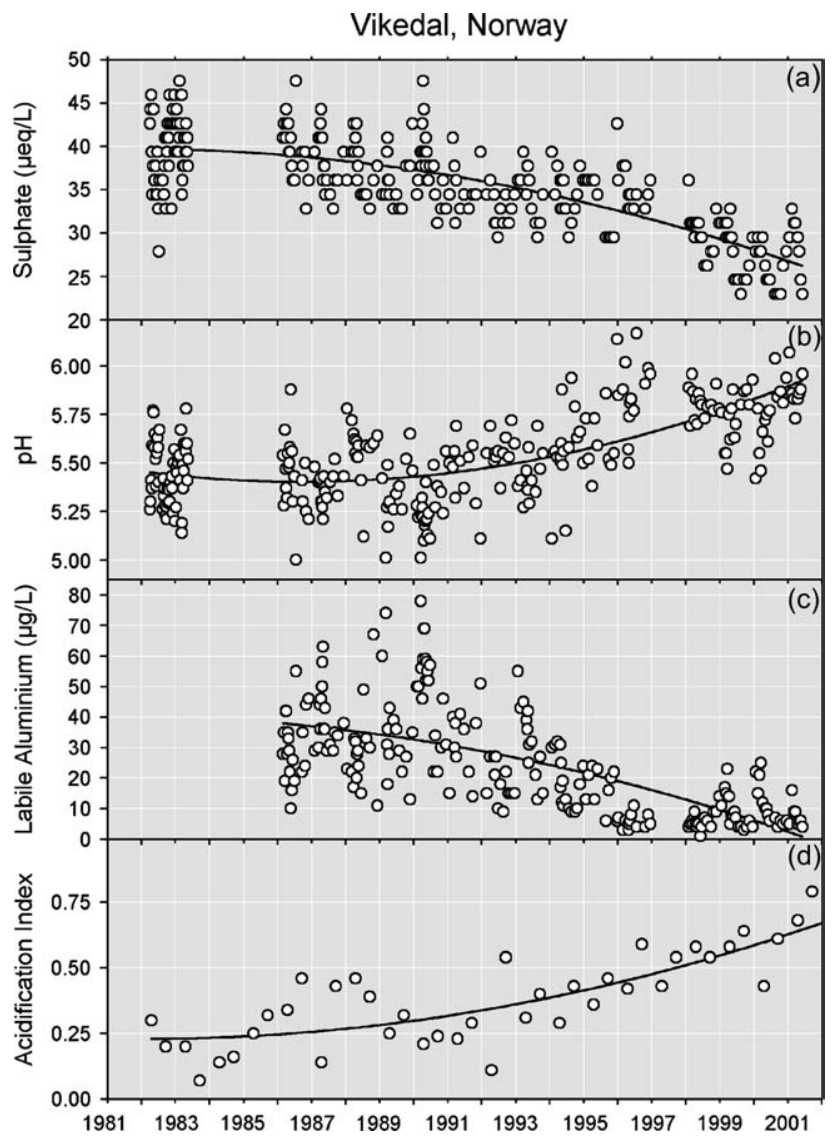

Fig. 9. Time series of (a) sulphate, (b) pH, (c) labile aluminium, and (d) Raddum invertebrate acidification index in Vikedal, an ICP Waters site in western Norway. Both sulphate and $\mathrm{pH}$ show improvement beginning in ca. 1990, a pattern common throughout the Nordic countries. Vikedal is one of the few ICP Waters sites with data for labile aluminium (c), which shows improvement beginning at the same time as sulphate and $\mathrm{pH}$. The acidification index begins to improve in ca. 1992. An index score of zero indicates an acidophilic fauna assemblage, while and index score of 1 indicates a normal, undamaged assemblage (data from the ICP Waters database; see also Fjellheim and Raddum, 2001). response to a strong decline in $\mathrm{SO}_{4}^{2-}$. Improvements in labile aluminium appear to have been simultaneous with increasing $\mathrm{pH}$ at this site. Regional declines in inorganic monomeric aluminium have also been reported for the Adirondack mountains (Driscoll et al., 2003).

\section{Do trends in deposition translate into trends in surface waters?}

A major goal of the work of ICP Waters is to evaluate the changes in surface water chemistry in relation to reductions in emission and deposition of $\mathrm{S}$ and $\mathrm{N}$.

It is difficult to compare absolute changes in $\mathrm{SO}_{4}^{2-}$ concentrations in surface waters and deposition, because of the effects of dry deposition and evapotranspiration. Both dry deposition and the evaporative concentration of ions in surface waters cause $\mathrm{SO}_{4}^{2-}$ concentrations in lakes and streams to be higher than those in precipitation. Higher concentrations lead to larger rates of change for $\mathrm{SO}_{4}^{2-}$ concentrations in surface waters than in precipitation. The percent change, however, should be relatively similar, assuming that dry deposition declines at the same rate as wet deposition, and that no changes in rates of evapotranspiration have occurred over time. There is a relatively good correlation between percentage change and concentration level, which means that sites with low concentrations of $\mathrm{SO}_{4}^{2-}$ show high percentage of change and sites with high concentrations of $\mathrm{SO}_{4}^{2-}$ show low percentage change. This will influence the comparison between regions, but the comparison between change in deposition and surface waters in the same region is unaffected.

We therefore present a comparison of percent change in $\mathrm{SO}_{4}^{2-}$ in precipitation and surface waters for each of the regions. European precipitation data are calculated for total deposition (wet plus dry) from EMEP Coordination Centre for Chemistry (CCC). Because no regional equivalent to EMEP exists in either the U.S. or Canada, we used wet deposition for North America and assume that percent changes in total deposition and wet deposition should be similar. U.S. data are from the U.S. National Atmospheric Deposition Program/ National Trends Network (NADP/NTN; National Atmospheric Deposition Program/National Trends Network, 2002) and Canadian data from the Canadian Air and Deposition Monitoring Network (CAPMoN; Ro and Vet, 2003).

In general, rates of $\mathrm{SO}_{4}^{2-}$ decline are smaller in surface waters than in deposition for all regions in North America and most regions in Europe (Fig. 10) indicating a lagged response. This may reflect the desorption of $\mathrm{S}$ that has accumulated in catchment soils over the past century due to atmospheric deposition. 

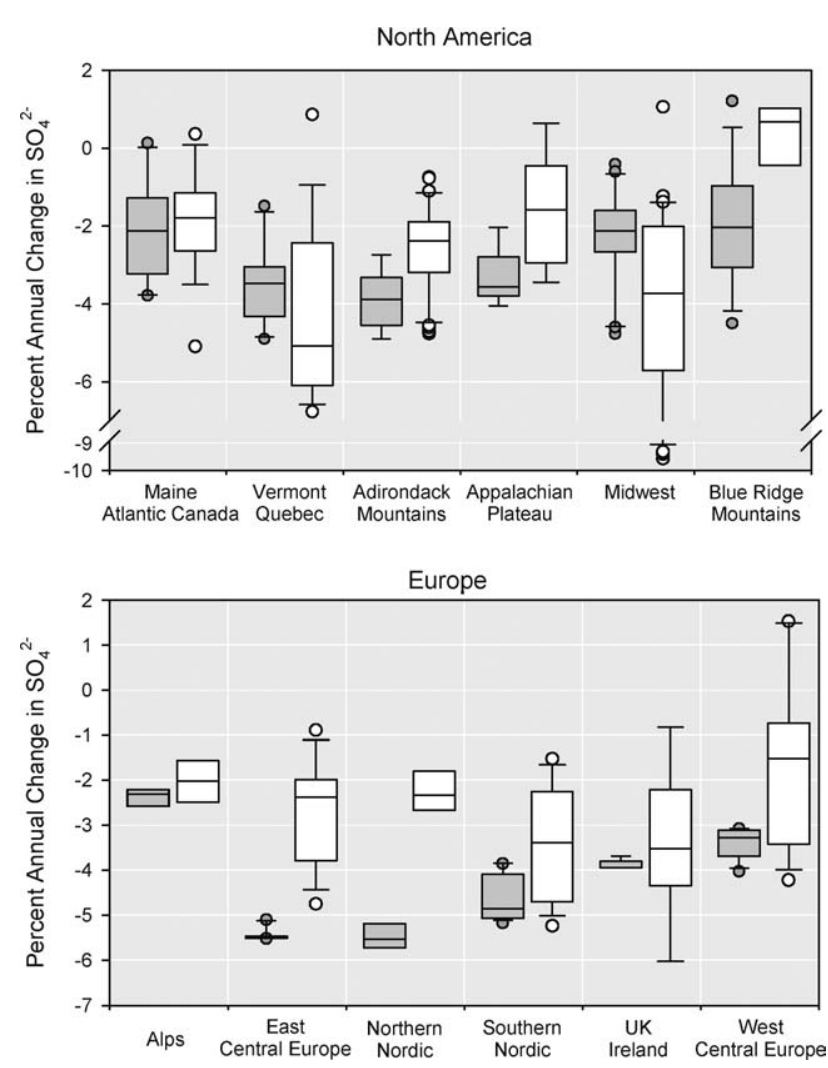

Fig. 10. Comparison of trend slopes for $\mathrm{SO}_{4}^{2-}$ in precipitation (left box - shaded) and $\mathrm{SO}_{4}^{2-}$ in surface waters (right box - clear) for the period 1990-2000 in acid sensitive regions of North America and Europe. North American deposition data are for trends in wet deposition concentrations. European deposition data are for trends in combined wet and dry deposition. Each box shows the range (25th to 75th percentiles, with line at median) of slopes; confidence intervals indicate 10th and 90th percentiles; dots indicate 5th and 95th percentiles.

Desorption of stored $\mathrm{S}$ has the effect of damping the trends in surface water $\mathrm{SO}_{4}^{2-}$ and slowing the rate of decline. One exception to the pattern in North America is in the Upper Midwest region of the U.S. (Fig. 10), where most lakes are seepage lakes. Here, the soils play only a minor role in controlling $\mathrm{SO}_{4}^{2-}$ concentrations, and declines in lake $\mathrm{SO}_{4}^{2-}$ concentrations are driven by dilution, following the drought that affected this area in the late 1980s and early 1990s (Stoddard et al., 2003). In Europe, both the Alps and the UK/Ireland regions show approximately the same percentage change in precipitation and surface waters indicating a very direct response on surface waters to changes in precipitation (see also Cooper, this issue).

\section{Does chemical improvement lead to biological recovery?}

As mentioned earlier, the ultimate goal of emissions reductions programs aimed at reducing the effects of acidic deposition is biological recovery-the re-establishment of sensitive taxa that were harmed or lost during the process of acidification. While we have the luxury of being able to assess chemical improvement over large regions and many monitoring sites, the existence of biological data relevant to biological recovery is much more limited. We may try to infer biological recovery from the stages of improvement in biologically-relevant chemistry (e.g., especially $\mathrm{H}^{+}$and aluminium), but those inferences will always be uncertain in the absence of actual biological data.

Although regional biological data are not generally available (but see Monteith et al., this issue), good monitoring data for single sites do exist, and can help us determine whether our expectations of biological recovery following chemical improvement are warranted (Raddum, 2003). An example is shown in Fig. 9 for Vikedal, one of the ICP Waters sites in western Norway. Strong declines in $\mathrm{SO}_{4}^{2-}$ have led to improvement in $\mathrm{pH}$ beginning in ca. 1990. Results for Raddum's acidification index (Raddum and Fjellheim, 1984) suggest that acid-sensitive invertebrates began to return in ca. 1992, and their abundance has continued to increase through the present. The Raddum index is a measure of acidification status based on presence/absence of sensitive invertebrate species. Similar results were found in Swedish lakes where statistically significant increase in another acidity biotic index was found for 11 out of 20 lakes (Wilander and Lundin, 2000).

\section{Conclusions}

The results from this work show that emission controls are working. Overall, the extent of recovery from acidification in Europe and North America varies over time, between regions, and between sites within regions, depending on a range of factors including the magnitude of deposition change and catchment characteristics. In general, however, there is clear evidence that reduced $\mathrm{S}$ deposition has led to significant improvements in the chemical status of acidified surface waters throughout Europe and North America. However future recovery can be changed by many factors, such as climate change and increased leaching of $\mathrm{N}$ (Skjelkvåle et al., 2003a). Specifically, for the key indicators of recovery:

- $\mathrm{SO}_{4}^{2-}$ concentrations are declining in 11 of 12 regions examined. The Blue Ridge region of the U.S., where decreases in $\mathrm{SO}_{4}^{2-}$ are not expected, is the only region not exhibiting significant regional decreases in $\mathrm{SO}_{4}^{2-}$.

- In general, $\mathrm{SO}_{4}^{2-}$ declines in surface waters are smaller than the declines observed in precipitation, suggesting some buffering of the $\mathrm{SO}_{4}^{2-}$ decline by soil processes. 
- $\mathrm{NO}_{3}^{-}$concentrations increased in one region (the Alps), decreased in three North American regions, and were unchanged in all other regions examined.

- Most regions (7 out of 12) showed improvement in at least one indicator of chemical recovery: Gran alkalinity (measured), acid neutralizing capacity (calculated) and $\mathrm{pH}$. The Maine and Atlantic Canada region was unusual in showing increasing acidification.

- DOC (an indicator of natural organic acidity) increased significantly in 6 out of 12 regions. All but one region had trends suggestive of increasing DOC. The mechanisms responsible for widespread increases in DOC are not currently known.

- While this paper focused on chemical trends, because chemical data are much more available, the observed trends in biologically-relevant chemistry should be facilitating biological recovery. Limited biological monitoring data from the ICP Waters network indicate that biological improvement may begin to occur after some lag time. Invertebrate data from one Norwegian stream suggest biological improvement lags chemical improvement by one or two years.

\section{Acknowledgements}

We greatly acknowledge all countries making national monitoring data available for international assessments within ICP Waters. The ICP Waters Programme Centre is funded by Norwegian Pollution Control Authority. Information from the U.S. has been funded in part by the U.S. Environmental Protection Agency. It is being distributed for peer review, and has not been approved for publication. The contents do not necessarily reflect the views of the Agency, nor does mention of trade names or commercial products constitute endorsement or recommendation for use. The authors gratefully acknowledge the Canadian National Atmospheric Chemistry (NAtChem) Database and Environment Canada for the provision of the CAPMoN data used in this publication.

\section{References}

Aber, J.D., Ollinger, S.V., Driscoll, C.T., 1997. Modeling nitrogen saturation in forest ecosystems in response to land use and atmospheric deposition. Ecological Modeling 101, 61-78.

Aber, J.D., Goodale, C.L., Ollinger, S.V., Smith, M.-L., Magil, A.H., Martin, M.E., Hallett, R.A., Stoddard, J.L., 2003. Is nitrogen deposition altering the nitrogen status of Northeastern forests? Bioscience 53, 375-389.

Altman, D., Bryant, T., Gardner, M., Machin, D., 2000. Statistics with Confidence. BMJ Books, London.

Barret, K., Aas, W., Ajellbrekke, A.G., Tarrason, L., Schaug, J., 2000. An evaluation of trends for concentrations in air and precipitation.
In: Schaug, J. (Ed.), Transboundary Acidification and Eutrophication in Europe. EMEP Summary Report 2000. Norwegian Meterorological Institute, Oslo, Norway, pp. 31-58.

Bull, K.R., Achermann, B., Bashkin, V., Chrast, R., Fenech, G., Forsius, M., Gregor, H.-D., Guardans, R., Haussmann, T., Hayes, F., Hettelingh, J.-P., Johannessen, T., Kryzanowski, M., Kucera, V., Kvaeven, B., Lorenz, M., Lundin, L., Mills, G., Posch, M., Skjelkvåle, B.L., Ulstein, M.J., 2001. Coordinated effects monitoring and modelling for developing and supporting international air pollution control agreements. Water Air and Soil Pollution 130, 119-130.

Church, M.R., Shaffer, P.W., Eshleman, K.N., Rochelle, B.P., 1990. Potential effects of sulphur deposition on stream chemistry in the Southern Blue Ridge Province. Water Air and Soil Pollution 50, $39-48$.

Cooper, D.M. Evidence of sulphur and nitrogen deposition signals at the United Kingdom Acid Waters Monitoring Network sites. Environmental Pollution, this issue.

Cosby, B.J., Hornberger, G.M., Wright, R.F., Galloway, J.N., 1986. Modelling the effects of acid deposition: Control of long-term sulfate dynamics by soil sulfate adsorption. Water Resources Research 22, 1283-1291.

Couture, S., 1995. Response of the Laflamme Lake Watershed, Quebec, to reduced sulphate deposition (1991-1992). Canadian Journal of Fisheries and Aquatic Science 52, 1936-1943.

Curtis, C.J., Evans C.D., Helliwell, R.C., Monteith, D.T. Nitrate leaching as a confounding factor in chemical recovery from acidification in UK upland waters. Environmental Pollution, this issue.

Davies, J.J.L., Jenkins, A., Monteith, D., Evans, C., Cooper, D.M. Trends in surface water chemistry of acidified UK freshwaters, 1988-2002. Environmental Pollution, this issue.

Dise, N.B., Wright, R.F., 1995. Nitrogen leaching from European forests in relation to nitrogen deposition. Forest Ecology and Management 71, 153-161.

Driscoll, C.T., Fuller, R.D., Schecher, W.D., 1989. The role of organic acids in the acidification of surface waters in the eastern U.S. Water Air and Soil Pollution 43, 21-40.

Driscoll, C.T., Driscoll, K.M., Roy, K.M., Mitchell, M.J., 2003. Chemical response of lakes in the Adirondack region of New York to declines in acidic deposition. Environmental Science and Technology 37, 2036-2042.

Evans, C.D., Freeman, C., Monteith, D.T., Reynolds, B., Fenner, N., 2002. Climate change - terrestrial export of organic carbon reply. Nature 415,862 .

Evans, C., Monteith, D.T., Cooper, D.M. Long-term increases in surface water dissolved organic carbon: observations, possible causes and environmental impacts. Environmental Pollution, this issue.

Fjellheim, A., Raddum, G.G., 2001. Acidification and liming of River Vikedal, western Norway. A 20 year study of responses in the benthic invertebrate fauna. Water Air and Soil Pollution 130, 1379-1384.

Freeman, C., Evans, C.D., Monteith, D.T., Reynolds, B., Fenner, N., 2001. Export of organic carbon from peat soils. Nature 412, 785.

Galloway, J.N., Norton, S.A., Church, M.R., 1983. Freshwater acidification from atmospheric deposition of sulfuric acid: A conceptual model. Environmental Science and Technology 17, $541-545$

Henriksen, A., Skjelvále, B.L., Mannio, J., Wilander, A., Harriman, R., Curtis, C., Jensen, J.P., Fjeld, E., Moiseenko, T., 1998. Northern European Lake Survey, 1995. Ambio 27 (2), 80-91.

Hirsch, R.M., Slack, J.R., 1984. A non-parametric trend test for seasonal data with serial dependence. Water Resources Research 20, 727-732

Hirsch, R.M., Slack, J.R., Smith, R.A., 1982. Techniques of trend analysis for monthly water quality analysis. Water Resources Research 18, 107-121. 
International Cooperative Programme on Assessment and Monitoring of Acidification of Rivers and Lakes, 1995. Programme Manual. Programme Centre, Norwegian Institute for Water Research, Oslo.

Jeffries, D.S., Semkin, R.G., Beall, F.D., Franklyn, J., 2002. Temporal trends in water chemistry in the Turkey Lakes watershed, Ontario, Canada, 1982-1999. Water Air and Soil Pollution Focus 2, 5-22.

Jeffries, D.S., Clair, T., Couture, S., Dillon, P., Dupont, J., Keller, W., McNicol, D., Turner, R., Vet, R., Weever, R., 2003. Assessing recovery of lakes in southeastern Canada from acidic deposition. Ambio 32, 176-182.

Kamari, J., Forsius, M., Kortelainen, P., Mannio, J., Verta, M., 1991. Finnish lake survey - present status of acidification. Ambio 20, 23-27.

Kirchner, J.W., Lydersen, E., 1995. Base cation depletion and potential long-term acidification of Norwegian catchments. Environmental Science and Technology 29, 1953-1960.

Lawrence, G.B., David, M.B., Lovett, G.M., Murdoch, P.S., Burns, D.A., Stoddard, J.L., Baldigo, B.P., Porter, J.H., Thompson, A.W., 1999. Soil calcium status and the response of stream chemistry to changing acidic deposition rates. Ecological Applications 9 (3), 1059-1072.

Loftis, J.C., Taylor, C.H., 1989. Detecting acid precipitation impacts on lake water quality. Environmental Management 13, 529-539.

Monteith, D.T., Hildrew, A.G., Flower, R.J., Raven, P.J., Beaumont, W.R.B., Collen, P., Kreiser, A., Shilland, E.M., Winterbottom, J.H. Biological responses to the chemical recovery of acidified fresh waters in the UK. Environmental Pollution, this issue.

National Atmospheric Deposition Program/National Trends Network, 2002. NADP/NTN Annual Data Summary. Precipitation Chemistry in the United States, Illinois State Water Survey, Champaign, Illinois.

Raddum, G.G., 2003. Is biology failing to recover from acidification? In: Skjelkvåle, B.L. (Ed.), The 15-year Report: Assessment and Monitoring of Surface Waters in Europe and North America; Acidification and Recovery, Dynamic Modeling and Heavy Metals. ICP Waters Report 73/2003, Norwegian Insititute for Water Research, Oslo, Norway.

Raddum, G.G., Fjellheim, A., 1984. Acidification and early warning organisms in freshwater in western Norway. Verh. International Verein. Limnol. 22, 1973-1980.

Ro, C.U., Vet, R.J., 2003. Analyzed Data Fields from the National Atmospheric Chemistry Database (NAtChem) and Analysis Facility, Air Quality Research Branch. Meteorological Service of Canada, Environment Canada, Toronto, Canada.

Rogora, M., Marchetto, A., Mosello, R., 2001. Trends in the chemistry of atmospheric deposition and surface waters in the Lago Maggiore watershed. Hydrology and Earth System Science 5, 379-390.

SAS Institute Inc., 1988. SAS/STAT User's Guide, Release 6.03 Edition. SAS Institute, Inc., Cary, NC.

Skjelkvåle, B.L., Mannio, J., Wilander, A., Andersen, T., 2001a. Recovery from acidification of lakes in Finland, Norway and Sweden. Hydrology and Earth System Sciences 5, 273-541.

Skjelkvåle, B.L., Stoddard, J.L., Andersen, T., 2001b. Trends in surface water acidification in Europe and North America (19891998). Water Air and Soil Pollution 130, 787-792.
Skjelkvåle, B.L., Evans, C., Larssen, T., Hindar, A., Raddum, G.G., 2003a. Recovery from acidification in European surface waters: a view to the future. Ambio 32, 170-175.

Skjelkvåle, B.L., Stoddard, J.L., Jeffries, D.S., Tørseth, K., Høgåsen, T., Bowman, J., Licsko, I., Lyulko, I., Mannio, J., Monteith, D., Mosello, R., Rogora, M., Rzychon, D., Srybny, A., Talkop, R., Vesely, J., Wieting, J., Wilander, A., Worstztynowicz, A., 2003b. Trends in surface water chemistry 1990-2001. In: Skjelkvåle, B.L. (Ed.), The 15-Year Report: Assessment and Monitoring of Surface Waters in Europe and North America; Acidification and Recovery, Dynamic Modeling and Heavy Metals. ICP Waters Report 73/2003, Norwegian Institute for Water Research, Oslo, Norway.

Stoddard, J.L., 1994. Long-term changes in watershed retention of nitrogen: its causes and aquatic consequences. In: Baker, L.A. (Ed.), Environmental Chemistry of Lakes and Reservoirs. Advances in Chemistry Series 237. American Chemical Society, Washington, DC, pp. 223-284.

Stoddard, J.L., Jeffries, D.S., Lükewille, A., Clair, T.A., Dillon, P.J., Driscoll, C.T., Forsius, M., Johannessen, M., Kahl, J.S., Kellogg, J.H., Kemp, A., Mannio, J., Monteith, D., Murdoch, P.S., Patrick, S., Rebsdorf, A., Skjelkvåle, B.L., Stainton, M., Traaen, T., van Dam, H., Webster, K.E., Wieting, J., Wilander, A., 1999. Regional trends in aquatic recovery from acidification in North America and Europe. Nature 401, 575-578.

Stoddard, J.L., Traaen, T.S., Skjelkavale, B.L., Johannessen, M., 2001. Assessment of nitrogen leaching at ICP-Waters sites (Europe and North America). Water Air and Soil Pollution 130, 781-786.

Stoddard, J.L., Kahl, J.S., Deviney, F.A., DeWalle, D.R., Driscoll, C.T., Herlihy, A.T., Kellogg, J.H., Murdoch, P.S., Webb, J.R., Webster, K.E., 2003. Response of surface water chemistry to the Clean Air Act Amendments of 1990. EPA/620/R-03/001, U.S. Environmental Protection Agency, Corvallis, Oregon.

Streets, D.G., Tsai, N.Y., Akimoto, J., Oka, K., 2001. Trends in emissions of acidifying species in Asia, 1985-1997. Water Air and Soil Pollution 130, 187-192.

Tranvik, L.J., Jansson, M., 2002. Climate change - Terrestrial export of organic carbon. Nature 415, 861-862.

UNECE, 1999. The 1999 Protocol to Abate Acidification, Eutrophication and Ground-level Ozone. Document ECE/EB.AIR, United Nations Economic Commission for Europe, New York and Geneva.

Vesely, J., Majer, V., Norton, S., 2002. Heterogeneous response of central European streams to decreased acidic atmospheric deposition. Environmental Pollution 120, 275-281.

Wilander, A., Lundin, L., 2000. Recovery of surface waters and forest soils in Sweden. In: Warfvinge, P., Bertills, U. (Eds.), Recovery from Acidification in the Natural Environment. Present Knowledge and Future Scenarios. Report 5034, Swedish Environmental Protection Agency, Stockholm, Sweden, pp. 53-66.

Wright, R., Alewell, C., Cullen, J., Evans, C., Marchetto, A., Moldan, F., Prechetl, A., Rogora, M., 2001. Trends in nitrogen deposition and leaching in acid-sensitive streams in Europe. Hydrological Earth System Science 5, 299-310. 